\title{
Theurapeutic Response of Neoadjuvant Chemotherapy between Platinum and Ifosfamide Combination and Platinum, Vincristine and Bleomycin Combination in Cervical Carcinoma Stage IB2
}

\author{
Perbandingan Respons Terapi antara Kemoterapi Neoajuvan Kombinasi Platinum \\ dan Ifosfamide dengan Kombinasi Platinum, Vincristine dan \\ Bleomycin pada Karsinoma Serviks IB2
}

\author{
Kartiwa H Nuryanto, Sigit Purbadi \\ Division of Gynecologic Oncology \\ Department of Obstetrics and Gynecology \\ Faculty of Medicine University of Indonesia/ \\ Dr. Cipto Mangunkusumo Hospital
}

Jakarta

\begin{abstract}
Objective: To evaluate the theurapeutic response and acute toxicity of neoadjuvant chemotherapy between the combination of Platinum and Ifosfamide, and the combination of Platinum, Vincristine and Bleomycin in Cervical Carcinoma Stage IB2 and then continued with radical hysterectomy and pelvic lymphadenectomy.
\end{abstract}

Method: Thirteen samples received neoadjuvant chemotherapy of Platinum and Ifosfamide and 17 samples received neoadjuvant chemotherapy of Platinum, Vincristine and Bleomycin, after receiving the neoadjuvant chemotherapy, clinically complete response samples underwent radical hysterectomy and pelvic lymphadenectomy (PI VS PVB = 3 VS 1). Histopathology examination was performed to evaluate the presence of malignant viable cells at the cervix, pelvic lymph node metastasis and parametrium metastasis. Acute toxicity evaluation was performed based on gastrointestinal, genitourinarius and hematology sign and symptom.

Result: Theurapeutic response of PI is 1.12 higher than PVB $(p>0.05)$. Subanalysis of group response of PI is 1.962 higher than PVB. PI and PVB have the same risk to have pelvic lymph node metastasis, but not parametrial metastasis. There were no differences in terms of the risk of gastrointestinal, genitourinarius and hematologic toxicity between PI and PVB.

Conclusion: There was no statistical difference in clinical and pathological response, and also in acute toxicity between the two combination ( $\mathrm{p}>0.05)$.

[Indones J Obstet Gynecol 2016; 1: 47-51]

Keywords: acute toxicity, cervical carcinoma stage IB2, neoadjuvant chemotherapy, response

\begin{abstract}
Abstrak
Tujuan: Untuk mengevaluasi respons terapi dan toksisitas akut pada kasus karsinoma serviks stadium IB2 yang mendapatkan kemoterapi ajuvan kombinasi platinum dan ifosfamide dan kombinasi platinum, vincristine dan bleomycin, yang dilanjutkan dengan histerektomi radikal dan diseksi kelenjar getah bening.
\end{abstract}

Metode: Sebanyak 13 sampel mendapatkan kemoterapi neoajuvan kombinasi platinum dan ifosfamide dan sebanyak 17 sampel mendapatkan kemoterapi neoajuvan kombinasi platinum, vincristine dan bleomycin. Pasca pemberian kemoterapi neoajuvan, sampel dengan respons komplit, dilanjutkan dengan tindakan histerektomi radikal dan diseksi masing-masing kelenjar getah bening pelvis (PI VS PVB = 3 VS 1). Penilaian histopatologi dilakukan untuk penilaian adanya malignant viable cell di masa tumor, metastasis kelenjar getah bening pelvis dan parametrium. Penilaian toksisitas akut dilakukan pada gastrointestinal, genitourinarius dan hematologi.

Hasil: Respons terapi kombinasi PI adalah 1,12 kali lebih besar dibandingkan dengan kombinasi PVB $(p>0,05)$. Subanalisis respons kelompok terapi kombinasi PI adalah sebesar 1,962 kali lebih dibandingkan dengan kombinasi PVB ( $p>0,05)$. Kombinasi PI mempunyai risiko yang sama dengan kombinasi PVB dalam hal ditemukannya metastasis kelenjar getah bening pelvis, tetapi tidak untuk metastasis pada parametrium. Pada pemberian kemoterapi kombinasi PI, tidak ditemukan perbedaan risiko terjadinya toksisitas gastrointestinal, genitourinarius dan hematologi selama terapi dibandingkan dengan kombinasi PVB.

Kesimpulan: Tidak didapatkan perbedaan yang bermakna pada respons terapi secara klinis dan histopatologi, juga pada toksisitas akut antara kedua kombinasi ( $p>0,05)$.

[Maj Obstet Ginekol Indones 2016; 1: 47-51]

Kata kunci: karsinoma serviks stadium IB2, kemoterapi neoajuvan, respons, toksisitas akut

Correspondence: Kartiwa H Nuryanto. Department of Obstetrics and Gynecology, Faculty of Medicine University of Indonesia, Jakarta. Telephone: 0811-1488028; Email: kartiwa_h_nuryanto@yahoo.com

\section{INTRODUCTION}

Cervical cancer is the third most diagnosed cancer and the fourth cause of female mortality worldwide. From 13 pathology center in Indonesia, cer- vical cancer is the first rank among all cancers $(23,4 \%$ of 10 most common cancers in men and women). Data from university hospitals in 2007 stated that cervical cancer is the most gynecology 
cancer, followed by ovarian, endometrial, vulva and vaginal cancer. ${ }^{1,2}$

A study on cervical cancer at Dr. Cipto Mangunkusumo Hospital Jakarta stated that 5 years survival rate of cervical cancer stage I, II, III and IV is 50\%, 40\%, 20\% and 0\%. Marisa et. $\mathrm{al}^{3}$ in 2013 stated that 1-survival rate of cervical cancer stage IB-IIA that underwent radical hysterectomy and pelvic lymphadenectomy at RSCM is $96 \%$, while 2years is $90 \%$, 3-years is $83 \%$, 4-years is $73 \%$ and 5 -years is $71 \%$.

In stage IB2, the tumor size is bigger than $4 \mathrm{~cm}$ which makes it the most important predictor for local recurrence and smaller survival rate. The big tumor mass increases the risk of stromal invasion that leads to higher risk of lymph node metastasis. The neoadjuvant chemotherapy hopefully will decreased the size of the tumor so that the shrinkage of the tumor mass will decrease the risk of lymph node metastasis. ${ }^{4}$

Management for cervical cancer stage IB2 is still debatable among oncologists, as some prefer to have surgery while others have radiation/chemoradiation as the main management. Neoadjuvant chemotherapy before definitive management has been an option, Kim H.S. et $\mathrm{al}^{5}$ stated that even neoadjuvant chemotherapy has decreased the rate of adjuvant radiation after surgery by decreasing the tumor mass and the risk of lymph node metastasis, but it does not improve the survival rate compared to primary radical hysterectomy. Study on neoadjuvant chemotherapy of Platinum, Vincristine and Bleomycine on cervical cancer stage IB2 stated that it gives better response prior the surgery, that are $12 \%$ for clinical complete response and $81 \%$ for 2 -years-disease-free-survival rate. ${ }^{6-10}$ González-Martín et. al. ${ }^{11}$ also stated in a meta analysis that neoadjuvant chemotherapy followed by surgery is better than radiation only in terms of overall survival. Hwang YY et. al. ${ }^{12}$ reported his study on 10-years-observation of 80 patients with stage IB-IIB cervical cancer with tumor size of 4 cm after neodjuvant chemotherapy with Cisplatin, Bleomycine and Vincristine continued by radical hysterectomy, that there were 75 patients with tumor shrinkage, with 5 and 10 years-survival rate of $82 \%$ and $79,4 \%$. Hutapea et. al. ${ }^{13}$ in 2011 reported 10 negative clinical response and 7 positive clinical response $(n=17)$ based on RECIST with neoadjuvant chemotherapy (Cisplatin, Vincristine and Bleomycine). The positive clinical response consists of 2 clinical complete response and 5 clinical partial response. All clinical complete response revealed pathological complete response as well. Neoadjuvant chemotherapy of Cisplatin and Ifosfamide was also reported by Zanetta et. al. ${ }^{14}$ on cervical cancer stage IB2, with significant response and overall response rate of $84 \%$ (CI 95\% = 68\%94\%) and with tolerable toxicity.

At RSCM, neoadjuvant chemotherapy has been used as part of cervical-cancer-stage-IB2 management. The combination of the chemotherapy regimens are Platinum-Vincristine-Bleomycine (which is used earlier) and Platinum-Ifosfamide. This study will evaluate the response of both combination at RSCM, based on the clinical response, pathological response and toxicity.

\section{METHODS}

The study is an ambispective cohort which took place from April 2013 - August 2014 at The Divison of Oncology Gynecology, Department of Obstetrics and Gynecology, Medical Faculty University of Indonesia, Dr. Cipto Mangunkusumo Hospital Jakarta. The study population is cervical cancer stage IB2 who received neoadjuvant chemotherapy, either combination of platinum, vincristine and bleomycine, or combination of platinum and ifosfamide, the followed by radical hysterectomy and pelvic lymphadenectomy. Total samples needed were 62 samples for each group.

Since ambispective cohort was used as study design, retrospective and prospective samples were used. Inclusion criterias include complete medical records, cervical cancer stage IB2 that has been confirmed histopathologically and has completed 3-cycle of neoadjuvant chemotherapy, either with combination of PVB or PI, followed by radical hysterectomy and pelvic lymphadenectomy, and patients who agreed to participate in the study. Exclusion criteria include incomplete medical records, patients with pelvic and/or paraaortic lymphadenectomy based on imaging, patients with lung or bone or liver metastasis based on imaging, patients who did not complete 3-cycle neoadjuvant chemotherapy, patients with other cancers and patients who refused to participate in the study.

All samples that fulfilled inclusion and exclusion criteria, were given 3-cycle neoadjuvant chemotherapy. Assessment of clinical response was performed 3 weeks after the last neoadjuvant chemo- 
therapy at the latest. Samples with clinical complete response then underwent radical hysterectomy and pelvic lymphadenectomy. Histopathological examination of surgical specimen was performed to evaluate the malignant viable cells at the tumor mass, lymph node metastasis and parametrial metastasis. Patients with malignant viable cells at the tumor mass, lymph node metastasis and parametrial metastasis, then received adjuvant radiation/chemoradiation.

\section{RESULTS}

There were 13 samples that received combination of platinum and ifosfamide as neoadjuvant chemotherapy dan 17 samples that received combination of platinum, vincristine and bleomycine as neoadjuvant chemotherapy.

The age, education and profession distribution is found at Table 1 . The most age distribution is $38-48$ years, 8 samples $(61.5 \%)$ from combination of PI and 10 samples (58.9\%) from combination of PVB. There were 4 samples (30.8\%) of PI combination and 7 samples (41.1\%) of PVB combination at the age distribution of 49-59 years.

The education distribution showed that the most distribution is high school for combination of PI (38.4\%) and elementary for combination of PVB (53\%).
The chemotherapy response is divided into positive and negative response, in which positive response consists of clinical complete response and partial response, while negative response consists of stable disease and progressive disease. The response distribution can be seen on Table 2 .

There were $3(23.1 \%)$ clinical complete response of PI combination and $2(11.8 \%)$ clinical complete response of PVB combination. Subanalysis was performed to evaluate the response of clinical complete response and nonclinical complete response, which consists of clinical partial response, stable disease and progressive disease (PI vs $\mathrm{PVB}=3: 10$ vs $2: 15$ ).

The clinical complete response samples were then scheduled for radical hysterectomy and pelvic lymphadenectomy. Surgery was performed to all PI samples and only 1 PVB sample due to respectability reason (PI vs $\mathrm{PVB}=3$ vs 1 ).

Table 3. Distribution of Histopathological Result

\begin{tabular}{lccc}
\hline \hline Chemotherapy & MVC & LNM & PM \\
\hline PI combination $(\mathrm{n}=3)$ & $3(100 \%)$ & $3(100 \%)$ & $0(0 \%)$ \\
PVB combination $(\mathrm{n}=1)$ & $1(100 \%)$ & $1(100 \%)$ & $1(100 \%)$ \\
\hline \hline \multicolumn{4}{l}{ MVB: Malignant Viable Cells; LNM: Lymph node metastasis; }
\end{tabular}

PM: Parametrialmetastasis

Table 1. Demographic Data and Cancer Stage

\begin{tabular}{lcccc}
\hline \hline Demographic Data & $\begin{array}{c}\text { Combination of PI } \\
(\mathbf{n = 1 3})\end{array}$ & $\mathbf{\%}$ & $\begin{array}{c}\text { Combination of PVB } \\
(\mathbf{n = 1 7})\end{array}$ & \% \\
\hline Age (years) & & & 10 & 58.9 \\
\hline $38-48$ & 8 & 61.5 & 7 & 41.1 \\
$49-59$ & 4 & 30.8 & 0 & 0 \\
$\geq 60$ & 1 & 7.7 & 1 & 5.9 \\
\hline Education & & & 9 & 53.0 \\
Undergraduate & 2 & 15.4 & 3 & 17.6 \\
Elementary & 4 & 30.8 & 4 & 23.5 \\
Junior High & 1 & 7.7 & 0 & 0 \\
Senior High & 5 & 38.4 & 7.7 & 0 \\
Bachelor & 1 & & & \\
\hline \hline
\end{tabular}

Table 2. Distribution of Response based on Tumor Size after Neoadjuvant Chemotherapy (RECIST)

\begin{tabular}{lcccc}
\hline \hline Response & Complete & Partial & Stable disease & Progressive \\
\hline PI combination $(n=13)$ & $3(23,1 \%)$ & $3(23,1 \%)$ & $2(15,4 \%)$ & $5(38,4 \%)$ \\
PVB combination $(n=17)$ & $2(11,8 \%)$ & $5(29,4 \%)$ & $1(5,9 \%)$ & $9(52,9 \%)$ \\
\hline \hline
\end{tabular}


Based on histopathological examination, malignant viable cells and positive lymph nodes metastasion were found in all complete response samples. Parametrial metastasis occurred only in combination of PVB. See Table 3.

Acute toxicity was divided into 3 categories, which are gastrointestinal, genitourinary and hematology. All samples in both combination reported abdominal discomfort and nausea without the need of medical management. Genitourinary toxicity was not found at PI samples but found at $2(11,7 \%)$ PVB samples. Hematology toxicity, that is $\mathrm{Hb}$ level $9.5-10.9 \mathrm{gr} \%$ or leucocyte $<3.900 / \mathrm{m}^{3}$, was reported at $4(30.8 \%)$ PI samples and 5 (29.4\%) PVB samples. See Table 4.

Table 4. Distribution of Acute Toxicity

\begin{tabular}{lccc}
\hline \hline Toxicity & $\begin{array}{c}\text { Gastrointes- } \\
\text { tinal }\end{array}$ & $\begin{array}{c}\text { Genitourina } \\
\text { ry }\end{array}$ & Hematology \\
\hline $\begin{array}{l}\text { Combination of } \\
\text { PI (n=13) }\end{array}$ & $13(100 \%)$ & $0(0 \%)$ & $4(30.8 \%)$ \\
$\begin{array}{l}\text { Combination of } \\
\text { PVB (n=17) }\end{array}$ & $17(100 \%)$ & $2(11.8 \%)$ & $5(29.4 \%)$ \\
\hline \hline
\end{tabular}

\section{DISCUSSION}

Total samples collected were 13 samples for PI combination and 7 samples for PVB combination. As the samples were not able to reach the minimal amount, it was realized that the power of the study might be less and be considered as a preliminary report.

The mean and median of age distribution for PI combination are 47.3 and 46 years old, while for PVB combination are 47.5 and 47 years old. The age distribution showed similarity between 2 groups. Data from INASGO 2009-2013 stated that the most age distribution is $36-45$ years old, while in the study is 38-48 years old, so that it also showed similarity in the age distribution.

The main purpose of giving neoadjuvant chemotherapy is to decrease the tumor size to improve the respectability and decrease the risk factors for recurrency. Li et al. ${ }^{15}$ stated that neoadjuvant chemotherapy would decrease the risk of LVSI and stromal infiltration which finally would decrease the risks of lymph node metastasis.

Recist was used to evaluate the clinical response, which was performed 3 weeks after the last course of neoadjuvant chemotherapy. The response was divided into positive and negative response. The positive response was then divided into complete response and partial response, while the negative response was divided into stable and progressive disease. The RR of positive and negative response is 1.2 ( $p>0.05)$. It showed that PI combination has a better chance to give positive response compared to PVB combination, although the $p$ value showed insignificancy of the chance. Subanalysis RR was also calculated to evaluate the relation between the complete response and the group of partial response, stable and progressive disease. The RR is 1.96 ( $p>0.05$ ), which showed that PI combination has also a better chance compared the PVB combination. The result of $\mathrm{p}$ value, which is $>0.05$, showed that the chance although is 1.96 is statistically insignificant. The RRs could be considered as preliminary RRs in evaluating the clinical response of PI and PVB combination. Both insignificant values for both RRs might be due to the number of samples collected, so that further study with more samples is needed. The insignificant result might also due to bio-molecular reasons which in this study was not analyzed. Colombo et $\mathrm{al}^{16}$, in a critical review stated that there was not enough data to show the superiority of each combination as neoadjuvant chemotherapy for cervical cancer before the definitive procedure, so a study to evaluate the chemotherapy combination is needed.

In histopathological response, the main purpose is to evaluate the presence of malignant viable cell, lymph node and parametrial metastasis. The histopathological response should correspond to the clinical response. The categories used $\operatorname{are}^{17}$ : Pathological complete response, in which there is no more residual or viable tumor at the surgery specimen, tumor mass and/or lymph node (TONO M0). Near-complete or Microscopic Response, in which one or more focuses or malignant viable cells measuring less than $1 \mathrm{~mm}$ at the surgery specimen, tumor mass and/or lymph node. Pathological partial response, in which the residual mass measuring more than $1 \mathrm{~mm}$ at the surgery specimen, tumor mass and/or lymph node.

As it was mentioned that all clinical complete response of PI combination $(n=3)$ underwent surgery while only 1 of PVB combination. The RR of malignant viable cell at the tumor mass and lymph node metastasis are 1 ( $\mathrm{p}$ value can not be calculated because there was no comparison), which showed that there was no difference in the chance of pathological complete response between PI and 
PVB combination in tumor mass and pelvic lymph node. The RR of parametrial metastasis is 4 ( $p>0.05$ ), which not only showed that there was a positive association between the neoadjuvant chemotherapy and the parametrial metastasis, but also showed that PI combination has a better chance to eliminate the risk of parametrial metastasis compared to PVB combination.

These data showed that clinical complete response does not correspond to pathological complete response in the presence of malignant viable cell and lymph node metastasis. Pathological complete response should more be understood and taken into consideration as it plays important role in recurrency and survival.

RR for toxicity distribution of gastrointestinal is 1 ( $\mathrm{p}$ value can not be calculated because there was no comparison) and of hematology is 1.04 ( $p>0.62$ ), while of genitourinarius is $0(\mathrm{p}>0.05)$. It showed that there was no difference in acute gastrointestinal and hematology toxicity between PI and PVB combination, while there was no risk of genitourinarius toxicity in PI combination compared to PVB combination. The insignificancy of all correlation might be due insufficient amount of samples in both groups.

All samples with malignant viable cell and lymph node metastasis received adjuvant radiation/ chemoradiation.

\section{CONCLUSIONS}

Clinical and histopathological response and also the acute toxicity of PI and PVB combination as neoadjuvant chemotherapy does not differ significantly. The clinical response does not correspond to histopathological response, where it should be taken for consideration to evaluate the risk of recurrency and survival. Further study should be done not only to evaluate both clinical and histopathological response of neoadjuvant chemotherapy of PI and PVB combination, but also to evaluate which combination among several combination used by oncologist give a better result.

\section{REFERENCES}

1. Ferlay J, Shin H, Bray F et al. GLOBOCAN, Cancer Incidence and Mortality Worldwide: IARC Cancer Base 2008; 10

2. Nuranna L, Azis F, Cornain S et al. Cervical cancer prevention program in Jakarta, Indonesia: See and Treat model in developing country. J Gynecol Oncol, 2012; 23(3): 147-52.
3. Anindya M, Purbadi S, Prihartono J. Kesintasan pasien kanker serviks stadium awal pasca histerektomi radikal beserta faktor-faktor yang mempengaruhinya di RSUPN Cipto Mangunkusumo tahun 2005-2010. Jakarta: Universitas Indonesia 2013.

4. Yun-Hyun C, Dae-Yeon K, Jong-Hyeok K, et al. Comparative study of neoadjuvant chemotherapy before radical hysterectomy and radical surgery alone in stage IB2-IIA bulky cervical cancer. J Gynecol Oncol. 2009; 20(1): 22-7.

5. Kim HS, Sardi JE, Katsumata N, et al. Efficacy of neoadjuvant chemotherapy in patients with FIGO stage IB1 to IIA cervical cancer: An international collaborative meta-analysis. J Cancer Surg. 2013; 39: 115-24.

6. Sardi J, Sananes C, Giaroli A, et al. Results of a prospective randomized trial with neoadjuvant chemotherapy in stage IB, bulky, squamous carcinoma of the cervix. Gynecol Oncol 1993; 49: 156-65.

7. Stewart LA, Tiernay JF. Neoadjuvant chemotherapy and surgery versus standard radiotherapy for locally advanced cervical cancer: a meta-analysis using individual patient data from randomized controlled trials. Proc ASCO. 2002; 21: 207a.

8. Eddy GL, Manetta A, Alvarez RD, et al. Neoadjuvant chemotherapy with vincristine and cisplatin followed by radical hysterectomy and pelvic lymphadenectomy for FIGO Stage 1B bulky cervical cancer: a Gynecologic Oncology Group pilot study. Gynecol Oncol 1995; 57: 412-6.

9. Benedetti-Panici P, Greggi S, Colombo A. Neoadjuvant chemotherapy and radical surgery versus exclusive radiotherapy in locally advanced squamous cell cervical cancer: results from the Italian Multicenter Randomized Study. J Clin Oncol 2001; 20: 179-88.

10. Chang TC, Lai CH, Hong JH, et al. Randomized trial of neoadjuvant cisplatin, vincristine, bleomycin and radical hysterectomy versus radiation therapy for bulky Stage IB and IIA cervical cancer. J Clin Oncol 2000; 18: 1740-7.

11. González-Martín A, González-Cortijo L, Carballo N, et al. The current role of neoadjuvant chemotherapy in the management of cervical carcinoma. Gynecologic Oncology. 2008; 110: S36-S40.

12. Hwang YY, Moon H, Cho SH. Ten-year survival of patients with locally advanced, stage Ib-IIb cervical cancer after neoadjuvant chemotherapy and radical hysterectomy. Gynecol Oncol. 2001; 82: 88-93.

13. Hutapea J, Kampono N, Sutrisna B, et al. Ekspresi VEGF-C Sebagai Prediktor Respon Kemoterapi Neoajuvan Dan Metastasis Ke Kelenjar Getah Bening Pada Kanker Leher Rahim Lesi Besar Jakarta: Universitas Indonesia; 2011.

14. Zanetta G, Lissoni A, Pellegrino A, et al. Neoadjuvant chemotherapy with cisplatin, ifosfamide and paclitaxel for locally advanced squamous-cell cervical cancer. Annals Oncol. 1998; 9: 977-80.

15. Rui L, Shen-tao L, Jing-ge S, et al. Prognostic value of responsiveness of neoadjuvant chemotherapy before surgery for patients with stage IB2/IIA2 cervical cancer. Gynecol Oncol 2013; 128: 524-9.

16. Colombo N, Peiretti M. Critical review of neoadjuvant chemotherapy followed by surgery for locally advanced cervical cancer. Int J Gynecol Cancer. 2010; 20: S47-8.

17. Myrna C, Chanona-Vilchis J, Cetina L, et al. Prognostic significance of pathological response after neoadjuvant chemotherapy or chemoradiation for locally advanced cervical carcinoma. International Seminars in Surg Oncol 2006; 3:3:3. 